\title{
The Enterococcus faecalis gene encoding the novel general stress protein Gsp62
}

\author{
Alain Rincé, ${ }^{1}$ Marilyne Uguen, ${ }^{2}$ Yoann Le Breton, ${ }^{1}$ \\ Jean-Christophe Giard, ${ }^{1}$ Sigrid Flahaut, ${ }^{1} \dagger$ Alain Dufour ${ }^{2}$ \\ and Yanick Auffray ${ }^{1}$
}

Author for correspondence: Alain Rincé. Tel: +332315655 23. Fax: +33231565311. e-mail: rince@ibba.unicaen.fr

\footnotetext{
1 Laboratoire de Microbiologie de I'Environnement, IRBA, Université de Caen, 14032 Caen Cedex, France

2 Laboratoire de Biologie et Chimie Moléculaires, EA 2594, Université de Bretagne Sud 56000 Vannes, France
}

\begin{abstract}
The Enterococcus faecalis general stress protein Gsp62 was purified using twodimensional gel electrophoresis and its $25 \mathrm{~N}$-terminal amino acid sequence determined. Analysis of the corresponding gene revealed that the gsp62 product is a 172 aa protein. Transcriptional analysis of gsp62 gave evidence for a monocistronic mRNA, the synthesis of which was induced at the onset of stationary phase and in response to heat shock, acid pH, detergents (i.e. SDS or bile salts), ethanol, tert-butyl hydroperoxide, sodium chloride and, to a lesser extent, hydrogen peroxide. 5' rapid amplification of CDNA ends by PCR experiments showed that gsp62 transcription initiates $30 \mathrm{nt}$ upstream of the ATG start codon. Although gsp62 expression was induced in response to various stresses, its disruption had no significant effect on the cell survival after each individual stress. Two-dimensional protein gels from wild-type and mutant cells revealed no pleiotropic effect of the mutation on protein synthesis. Transcriptional fusions with the lacL lacM $\beta$-galactosidase genes showed that an inverted repeat located upstream of the promoter is required for transcriptional induction by environmental stresses but not by entrance into stationary phase. Two distinct mechanisms responding to different signals are thus involved in gsp62 induction.
\end{abstract}

Keywords: Enterococcus faecalis, general stress protein, Gsp

\section{INTRODUCTION}

When grown under moderate stress conditions, bacteria may develop an adaptive response, allowing them to cope with subsequent more severe stresses. In general, this adaptation phenomenon appears to involve multiple genes encoding stress proteins, which can be specifically induced by a particular stress factor (specific stress proteins) or induced by several conditions (general stress proteins).

The Gram-positive bacterium Enterococcus faecalis is an ubiquitous micro-organism. Resident of the human and animal gut, it is introduced to the environment by means of faeces and subsequently disseminated to diverse niches. Ent. faecalis also has importance as a pathogen, ranking the second most important agent in

\footnotetext{
† Present address: Laboratoire de Biologie Cellulaire et Moléculaire, Université du Littoral-Côte d'Opale, Bassin Napoléon, BP120, 62327 Boulogne sur mer, Cedex, France.
}

Abbreviations: $\mathrm{tBOOH}$, tert-butyl hydroperoxide; 2-D, two-dimensional; IR, inverted repeat; RACE, rapid amplification of CDNA ends. total nosocomial infections. Its survival in the external environment is linked to its exceptional aptitude for coping with harsh conditions (Jett et al., 1994; Mundt, 1986). Physiological studies showed that Ent. faecalis is able to develop adaptive responses towards diverse stresses (Boutibonnes et al., 1993; Flahaut et al., 1996a, b, c; 1997a, b, c; 1998; Laplace et al., 1996). Moreover, analysis of protein synthesis during incubation of exponentially growing cells of Ent. faecalis with sublethal stresses led to the detection of the overexpression of 167 proteins. Six of these are induced by at least six different stress conditions and probably play an important physiological role in the non-specific stress response. These general stress proteins were named Gsp62 to Gsp67 (Rincé et al., 2000). Studies of proteins overexpressed during glucose exhaustion led to the identification of several glucose starvation proteins (Glsp) and to the characterization of a seventh general stress protein, Gls24, which is involved in bile salt resistance (Giard et al., 2000). Western blot analyses identified Gsp66 and Gsp67 as DnaK and GroEL chaperonins, respectively (Flahaut et al., 1997b), and 
their induction characteristics implied that their genes belong to the same regulon (Rincé et al., 2000). Recently, Gsp65 was identified as an organic hydroperoxide resistance protein (Ohr) involved in resistance to oxidative stress (Rincé et al., 2001). mRNA studies revealed a transcriptional induction of gsp65 in response to tertbutyl hydroperoxide $(\mathrm{tBOOH})$, heat shock, acid $\mathrm{pH}$, detergents (bile salts, SDS), ethanol, sodium chloride and $\mathrm{H}_{2} \mathrm{O}_{2}$.

In this paper, we describe Gsp62, a novel Ent. faecalis general stress protein. This was purified from twodimensional (2-D) protein gels and its $\mathrm{N}$-terminal sequence determined. The identification of the corresponding gene allowed sequence analyses, gene inactivation and expression studies.

\section{METHODS}

Bacterial strains, plasmids and culture conditions. Bacterial strains and plasmids used in this study are listed in Table 1. Ent. faecalis strains were grown at $37^{\circ} \mathrm{C}$ without shaking in brain heart infusion medium (BHI, Difco) or in M17 medium (Terzaghi \& Sandine, 1975) supplemented with $0.5 \%$ glucose (GM17). When necessary, erythromycin was added at a concentration of $150 \mu \mathrm{g} \mathrm{ml}^{-1}$. Viability was determined by spreading $0.5 \mathrm{ml}$ serial dilutions on BHI agar $(1.5 \% \mathrm{w} / \mathrm{v})$. Escherichia coli strain XL1Blue (Stratagene) and plasmid pUCB300 (Frère et al., 1993) were used for cloning a gsp62 internal fragment for integrational mutagenesis. Esc. coli strain DH5 $\alpha$ (Life Technologies) and plasmids pBluescript $\mathrm{SK}^{+}$(Stratagene) and pAK80 (Israelsen et al., 1995) were used for cloning the gsp62 promoter upstream of the lacL and lacM $\beta$-galactosidase genes. Esc. coli strains were cultivated under vigorous agitation at $37^{\circ} \mathrm{C}$ in LB medium (Sambrook et al., 1989) with ampicillin $\left(100 \mu \mathrm{g} \mathrm{m}^{-1}\right)$ or erythromycin $\left(150 \mu \mathrm{g} \mathrm{ml}^{-1}\right)$ added when required.

Construction of a gsp62 mutant by homologous recombination. To construct an insertional mutant with a disruption in gsp62, an internal fragment of 368 bp was PCR amplified with phosphorylated oligonucleotides P5 and P6 (Fig. 1a; Table 2), treated $30 \mathrm{~min}$ at $72{ }^{\circ} \mathrm{C}$ with $2.5 \mathrm{UPfu}$ polymerase (Stratagene) and cloned into the insertional vector pUCB300 previously digested with $S m a \mathrm{I}$ and dephosphorylated. The resulting plasmid obtained after transformation of Esc. coli XL1Blue was introduced into Ent. faecalis JH2-2. Integrations within gsp62 were verified in erythromycin-resistant colonies by PCR using primers P1 and P4 (Fig. 1a; Table 2) (data not shown) and by Southern blot hybridization (Fig. 2).

Adaptation and challenge treatments. Ent. faecalis $\mathrm{JH} 2-2$ cultures $(10 \mathrm{ml})$ were grown to an $\mathrm{OD}_{600}$ of 0.5 (midexponential growth phase). Bacteria were harvested by centrifugation and resuspended in BHI medium (control culture). Adaptation was conducted in the same medium incubated at $50{ }^{\circ} \mathrm{C}$ (heat shock), or at $37^{\circ} \mathrm{C}$ in medium supplied with (i) $4 \%(\mathrm{v} / \mathrm{v})$ ethanol, (ii) $0.08 \%(\mathrm{w} / \mathrm{v})$ bile salts (sodium cholate: sodium deoxycholate, $1: 1 \mathrm{v} / \mathrm{v}$ ), (iii) $0.01 \%(\mathrm{w} / \mathrm{v}$ ) SDS, (iv) $6.5 \%$ (w/v) NaCl, (v) $2.4 \mathrm{mM} \mathrm{H}_{2} \mathrm{O}_{2}$, (vi) lactic acid to adjust $\mathrm{pH}$ to $4 \cdot 8$, (vii) $\mathrm{NaOH}$ to adjust $\mathrm{pH}$ to $10 \cdot 5$, (viii) $2 \mathrm{mM}$ tBOOH. Adaptation treatments were performed for 30 min, except for $\mathrm{NaCl}$ (2 h).

Adapted and non-adapted cells (treated as described above) were harvested by centrifugation. Cells were resuspended in $10 \mathrm{ml} \mathrm{BHI}$ and incubated at $37^{\circ} \mathrm{C}$ (control) or at $62{ }^{\circ} \mathrm{C}$ to determine resistance to a thermal challenge. Other challenges were carried out at $37^{\circ} \mathrm{C}$ in medium supplied with (i) $22 \%$ (v/v) ethanol, (ii) $0.3 \%(\mathrm{w} / \mathrm{v})$ bile salts, (iii) $0.017 \%(\mathrm{w} / \mathrm{v}$ ) SDS, (iv) $28.5 \%$ (w/v) NaCl, (v) $45 \mathrm{mM} \mathrm{H}_{2} \mathrm{O}_{2}$, (vi) lactic acid to adjust $\mathrm{pH}$ to $3 \cdot 2$, (vii) $\mathrm{NaOH}$ to adjust $\mathrm{pH}$ to $11 \cdot 9$, (viii) $20 \mathrm{mM}$ tBOOH. Challenges were performed for $30 \mathrm{~min}$ except

Table 1. Bacterial strains and plasmids used in this study

\begin{tabular}{|c|c|c|}
\hline Strain or plasmid & Relevant characteristics & Reference or source \\
\hline \multicolumn{3}{|l|}{$\begin{array}{l}\text { Ent. faecalis } \\
\text { strains }\end{array}$} \\
\hline ATCC 19433 & & Jones \& Shattock (1960) \\
\hline JH2-2 & Rif $^{r}$ Fus $^{r}$ & Yagi \& Clewell (1980) \\
\hline \multicolumn{3}{|l|}{ Esc. coli strains } \\
\hline XL-1 Blue & $\begin{array}{l}\text { recA1 endA1 gyrA96 thi-1 hsdR17 supE44 relA1 } \\
\text { lac }\left[\mathrm{F}^{\prime} \text { proAB lacl }{ }^{\alpha} \mathrm{Z} \Delta M 15 \operatorname{Tn} 10\left(\text { Tet }^{\mathrm{r}}\right)\right]\end{array}$ & Stratagene \\
\hline DH $5 \alpha$ & 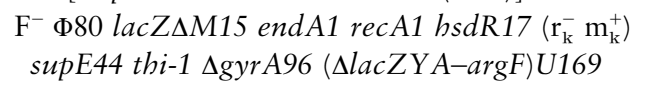 & Life Technologies \\
\hline \multicolumn{3}{|l|}{ Plasmids } \\
\hline pUCB300 & Esc. coli plasmid vector; Amp $^{\mathrm{r}}, \mathrm{Erm}^{\mathrm{r}}$ & Frère et al. (1993) \\
\hline pBluescript SK ${ }^{+}$ & Esc. coli plasmid vector; $\mathrm{Amp}^{\mathrm{r}}$ & Stratagene \\
\hline pAK80 & $\begin{array}{l}\text { Esc. coli-Ent. faecalis shuttle; promoter probe } \\
\text { vector for transcriptional fusions with } \\
\text { lacL-lacM } \beta \text {-galactosidase genes; } \text { Erm }^{\mathrm{r}}\end{array}$ & Israelsen et al. (1995) \\
\hline p17635 & Esc. coli plasmid vector; $A_{m p}{ }^{r}, K{ }^{r}{ }^{r}$ & Bardonnet \& Blanco (1992) \\
\hline pFWT62 & $\begin{array}{l}\text { pAK } 80 \text { containing the wild-type gsp62 promoter } \\
\text { (region }-246 \text { to }+107) \text { fused to the lacL-lacM } \\
\beta \text {-galactosidase genes }\end{array}$ & This study \\
\hline pFDE62 & $\begin{array}{l}\text { pFWT } 62 \text { with a } 15 \text { bp EcoRI fragment deleted in } \\
\text { the gsp } 62 \text { promoter region }\end{array}$ & This study \\
\hline
\end{tabular}




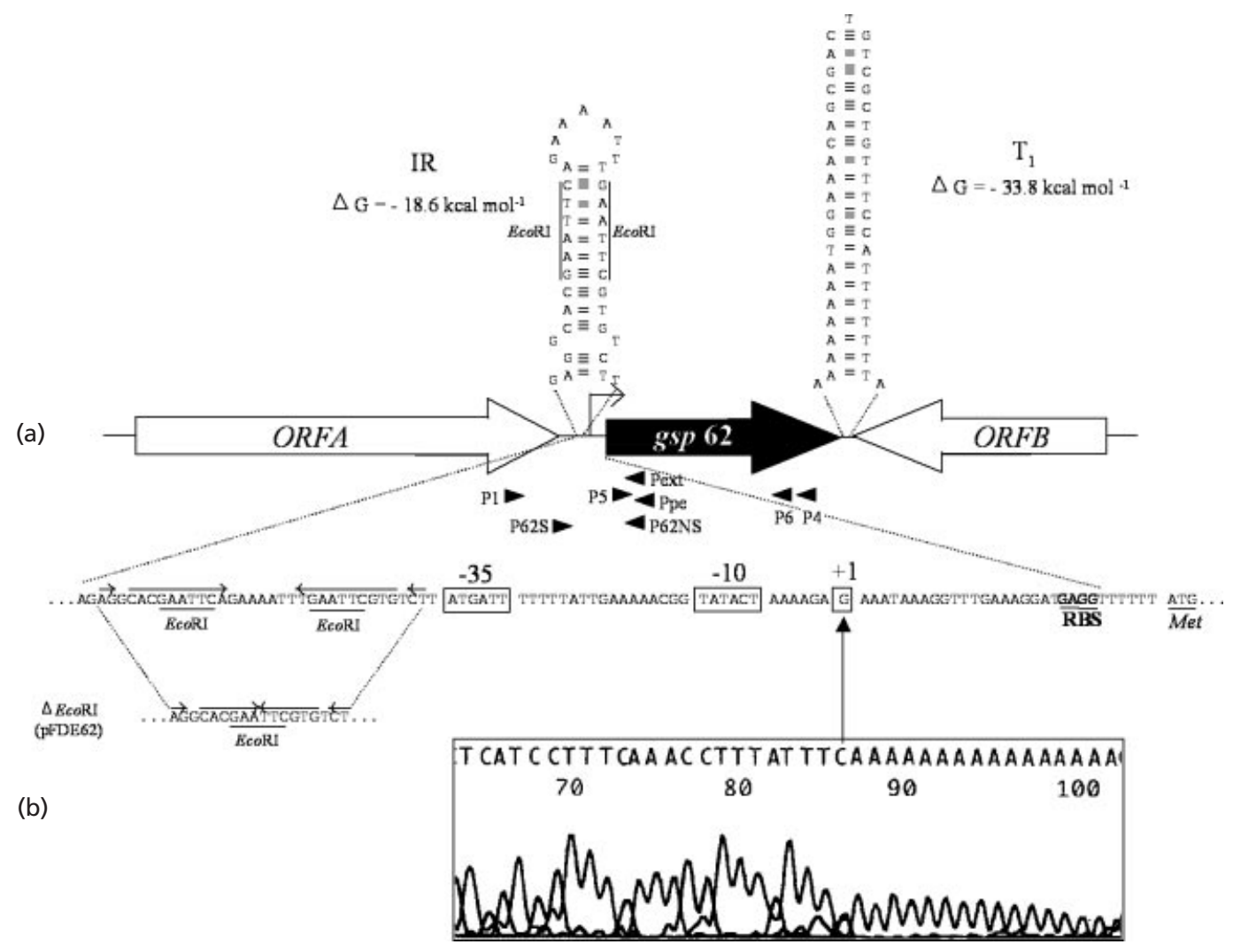

Fig. 1. (a) Genetic organization of the gsp62 chromosomal region. Large arrows represent the ORFs and their orientation shows the transcriptional direction. The nucleotide sequences of the gsp62 promoter region, of the putative rhoindependent terminator (T1) located immediately downstream of the gsp62 stop codon, and of the inverted repeat lying upstream of the gsp62 promoter (IR) are shown. The transcription initiation nucleotide $(+1)$ and the putative -35 and -10 motifs are boxed. The EcoRI sites used to delete a part of the IR within the gsp62 promoter are indicated. The sequence resulting from the deletion is presented and the IRs in the wild-type and in the deleted fragment are shown by convergent arrows. Primer positions are indicated by arrowheads. (b) Electrophoretogram obtained from $5^{\prime}$ RACE PCR experiment. The sequence in the electrophoretogram was obtained using primer Pext and $5^{\prime}$ A-tailed CDNA obtained with the $3^{\prime} / 5^{\prime}$ RACE kit. The last base (C) upstream of the $16 \mathrm{nt}$ A-tail corresponds to the first nucleotide transcribed. The corresponding $\mathrm{G}$ on the reverse complement strand is indicated above $(+1)$.

Table 2. Primers used for PCR, mutagenesis and $5^{\prime}$ RACE PCR experiments

\begin{tabular}{|c|c|c|}
\hline Primer & Sequence $\left(5^{\prime}-3^{\prime}\right)^{*}$ & Orientation $\dagger$ \\
\hline P1 & AGAAGTTGTGGATTTTGC & + \\
\hline P4 & CAATGTATCCGCGTAATTC & - \\
\hline P5 & GTTAACACAGAAACAGGGC & + \\
\hline P6 & GGAAACAAGCGTTGCATCT & - \\
\hline Ppe & TTGACAGGGGCATTACTCTC & - \\
\hline Pext & СТCTCACCAATGTGAAGCCCTGTT & - \\
\hline P62S & atgtaggATCCAAGCAATCGGCATTAG & + \\
\hline P62NS & ttaTactgCAGGGGCATTACTCTCACC & - \\
\hline
\end{tabular}

* Bases indicated in lower-case letters are not complementary to the target sequence. Underlined nucleotides correspond to Bam HI and Pst sites.

$\dagger+$, Primer directed towards the $3^{\prime}$ end of gsp62; -, primer in the opposite direction.

for the bile salts and SDS detergents (30 s). Samples $(0.5 \mathrm{ml})$ were removed, diluted in $0.9 \% \mathrm{NaCl}$ and poured in GM17 agar for the determination of c.f.u. numbers. Plates were incubated at $37^{\circ} \mathrm{C}$ for $48 \mathrm{~h}$. Each point of an experiment is the mean of duplicate platings and all experiments were repeated at least twice. 


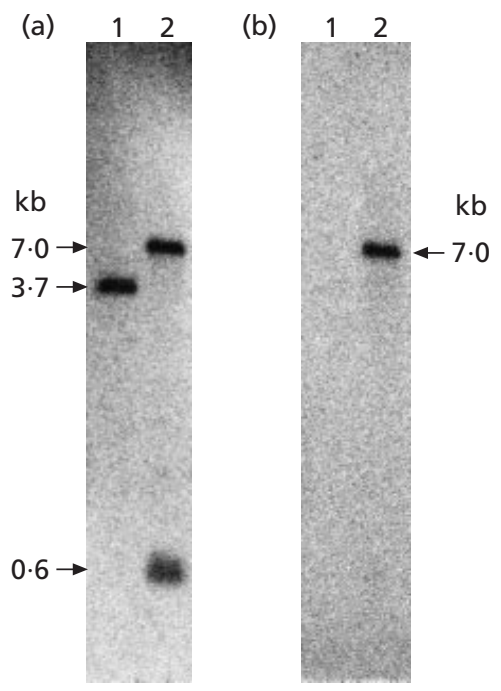

Fig. 2. Southern blots of total DNA extracted from wild-type Ent. faecalis JH2-2 (lanes 1) and a gsp62 mutant (lanes 2) and digested by EcoRI. Hybridizations were performed with ${ }^{32} \mathrm{P}$ labelled PCR fragment P5-P6 (a) or ${ }^{32}$ P-labelled pUCB300 vector (b).

Analysis of mRNA by Northern and dot blot experiments. Total RNA of Ent. faecalis JH2-2 was isolated from exponentially growing cells, from cells entering stationary phase or from stressed cells by using the RNeasy Midi Kit (Qiagen). For Northern blots, $10 \mu \mathrm{g}$ RNA was electrophoretically resolved per lane and transferred onto Hybond $-\mathrm{N}^{+}$membranes (Amersham International) using standard procedures (Sambrook et al., 1989). Sizes of transcripts were estimated by comparison with an RNA ladder (0.56-9.4 kb) (Amersham International). For dot blots, $1 \mu \mathrm{g}$ total RNA from cells incubated $10 \mathrm{~min}$ under the different individual stress conditions was spotted onto Hybond- $\mathrm{N}^{+}$membranes. Membranebound nucleic acids were hybridized at a temperature of $55^{\circ} \mathrm{C}$ in $1 \mathrm{M}$ sodium phosphate buffer ( $\mathrm{pH} 7 \cdot 0$ ) containing $5 \%$ SDS with a single-strand labelled probe complementary to gsp62 mRNA. After hybridization, membranes were washed twice in $2 \times \mathrm{SSC}, 0.1 \%$ SDS $(10 \mathrm{~min})$, twice in $0.5 \times \mathrm{SSC}, 0.1 \% \mathrm{SDS}$ $(10 \mathrm{~min})$ at $55^{\circ} \mathrm{C}$, and exposed to a storage phosphor screen (Packard Instrument Company) for $5 \mathrm{~h}$.

Preparation of the single-strand labelled probe was as follows: first, a DNA fragment was amplified by PCR from chromosomal DNA of Ent. faecalis JH2-2 with the primers P4 and P5 (Fig. 1a; Table 2). The probe was then synthesized by elongating the oligonucleotide $\mathrm{P} 4$ with Taq DNA polymerase, $2 \mu \mathrm{M}$ dCTP, dGTP and dTTP, $2 \mu \mathrm{Ci}(74 \mathrm{kBq})\left[\alpha^{32} \mathrm{P}\right] \mathrm{dATP}$ and $10 \mathrm{ng}$ of the previously obtained PCR DNA fragment as template. Thirty cycles of $1 \mathrm{~min}$ at $94^{\circ} \mathrm{C}, 1 \mathrm{~min}$ at $55^{\circ} \mathrm{C}$ and $1 \mathrm{~min}$ at $72{ }^{\circ} \mathrm{C}$ were performed.

Mapping of the transcriptional start site. The $5^{\prime}$ end of gsp62 mRNA was mapped from a $5^{\prime}$ RACE (rapid amplification of cDNA ends) PCR product obtained with the $3^{\prime} / 5^{\prime}$ RACE kit (Roche Molecular Biochemicals) using primer P6 (Fig. 1a; Table 2) for the reverse transcriptase reaction and polyA tailing and primer Ppe for PCR amplification (Fig. 1a; Table 2 ). The cDNA was then purified, analysed on a $6 \%$ polyacrylamide gel and sequenced by the dideoxy chain termination method with the ABI prism sequencing system (PE Biosystems) and primer Pext (Fig. 1a; Table 2).
Construction of promoter fusions. A $353 \mathrm{bp}$ fragment containing the wild-type $g s p 62$ promoter (nucleotide region -246 to +107 , relative to the transcriptional start site) was amplified by PCR using the primers P62S and P62NS (Fig. 1a; Table2), digested with BamHI and Pst I, and cloned into the BglII and PstI sites of the promoter probe vector pAK80, creating plasmid pFWT62. The insert was sequenced to ensure that the PCR reaction did not induce any mutations. A variant of pFWT62, bearing an EcoRI deletion which removes a part of the inverted repeat located upstream of the promoter (Fig. 1a) was constructed as follows. First, the $353 \mathrm{bp}$ fragment containing the wild-type gsp 62 promoter was cloned into the BamHI and Pst sites of the pBluescript vector and its sequence was determined to make sure that the PCR did not create any mutations. Then, the EcoRI site of the vector was eliminated by inserting the kanamycin resistance cassette from p17635 (Bardonnet \& Blanco, 1992) between the PstI and ApaI sites. The resulting plasmid was linearized by $E c o R I$ and self-ligated to obtain the 15 bp deletion within the gsp62 promoter region. The resulting 338 bp fragment was excised by digestion with Bam HI and PstI, purified and subcloned into the BglII and PstI sites of pAK80, yielding plasmid pFDE62. For both constructions, conservation of the three stop codons immediately upstream of the ribosome-binding site of lacL in pAK80 ensured that the coding region of $g s p 62$ was not translationally fused to the reporter gene. Plasmids pFWT62 and pFDE62 were introduced by electroporation as described below.

$\boldsymbol{\beta}$-Galactosidase assays. Cells grown in BHI and exposed to $4 \%$ ethanol or $0.3 \mathrm{M}$ sodium chloride were harvested by centrifugation and concentrated fivefold in Z buffer (Miller, 1972). Two hundred microlitres of bacterial suspension were treated as described by Israelsen et al. (1995) and $\beta$-galactosidase activity was expressed in Miller units calculated according to the equation: activity $=\left(\mathrm{OD}_{420} \times 1000\right) /\left(\mathrm{OD}_{600} \times 0 \cdot 2 \times\right.$ $\left.t_{(\min )}\right)(0 \cdot 2$ corresponding to the volume of cell suspension in $\mathrm{ml}$ ). Each point is the mean of at least three experiments.

Two-dimensional protein gel electrophoresis. Sample preparation and 2-D protein gel electrophoresis were carried out as described by Giard et al. (1997).

General molecular methods. Restriction endonucleases, T4 polynucleotide kinase, alkaline phosphatase and T4 DNA ligase were obtained from Roche Molecular Biochemicals, Amersham International and Eurogentec, and used according to the manufacturers' instructions. PCRs were carried out with $5 \mu \mathrm{g}$ chromosomal DNA from Ent. faecalis JH2-2 and 20 pmol primers, using Taq DNA polymerase (Sigma) or Ready To Go PCR Beads (Pharmacia Biotech). When necessary, PCR products were purified using the QIAquick Kit (Qiagen). Esc. coli and Ent. faecalis were transformed by electroporation with the Gene Pulser Apparatus (Bio-Rad), as described by Dower et al. (1988) and Holo \& Nes (1995), respectively. Plasmids were purified by using QIAprep Miniprep Kit (Qiagen). DNA and amino acid sequences were analysed using the Mac Vector program (Kodak, Scientific Imaging Systems) and database searches were performed with the BLAST program (Altschul et al., 1990). Other standard techniques were carried out as described by Sambrook et al. (1989).

\section{RESULTS}

\section{Identification of gsp62}

Proteins extracted from a $50 \mathrm{ml}$ culture of Ent. faecalis ATCC 19433 incubated for $2 \mathrm{~h}$ in the presence of $6.5 \%$ $\mathrm{NaCl}$ were separated by preparative 2-D electrophoresis 

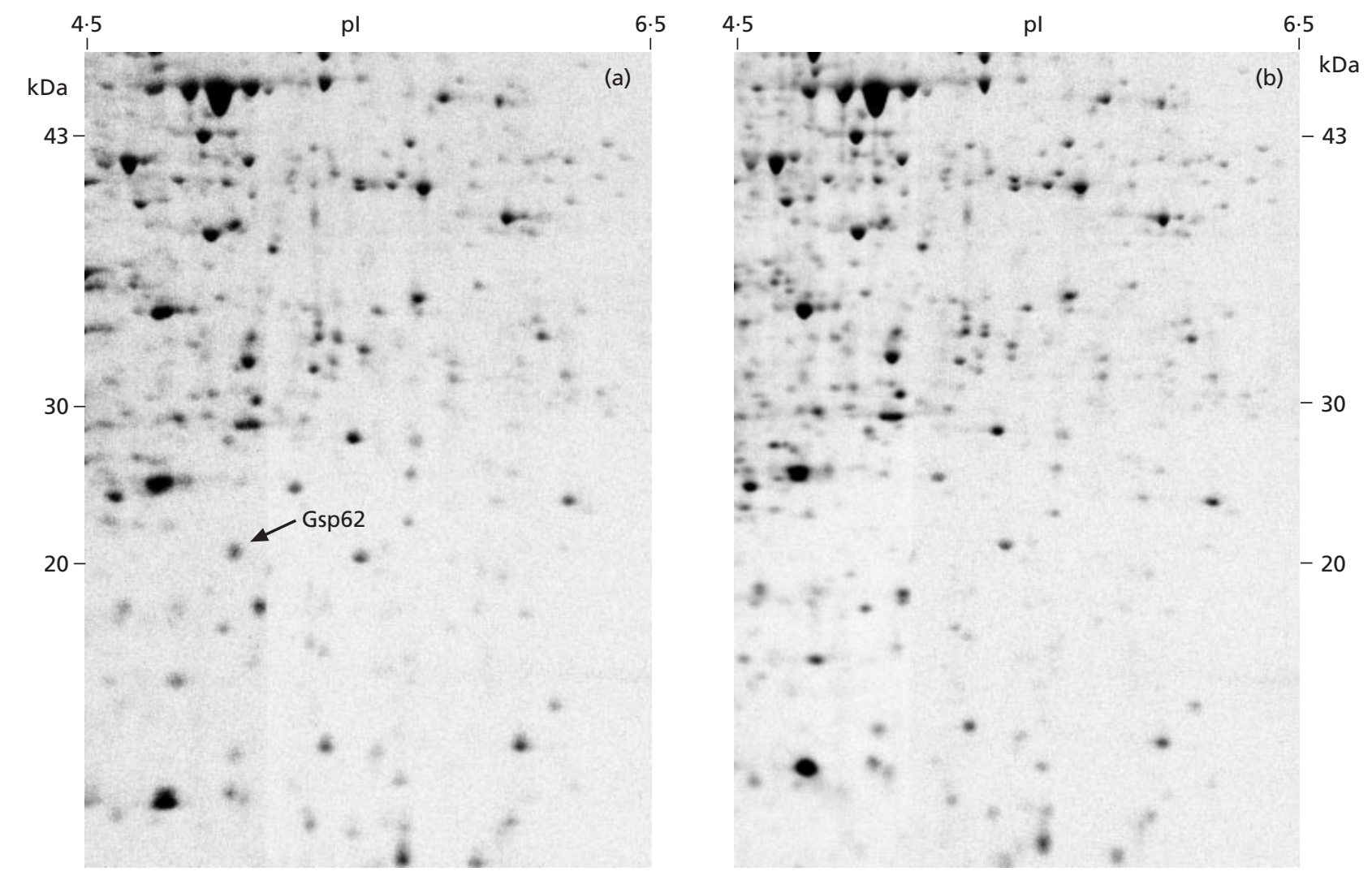

Fig. 3. Autoradiogram of 2-D protein gels of Ent. faecalis JH2-2 (a) and a gsp62 mutant (b). The pictures represent a part of the autoradiograms obtained after electrophoresis of proteins extracted from $5 \mathrm{ml}$ culture aliquots of exponentially growing cells, pulse-labelled with $250 \mu \mathrm{Ci}(9 \cdot 25 \mathrm{MBq}){ }^{35} \mathrm{~S}$ ]methionine/cysteine 'protein-labelling mix' (New England Nuclear Co., $1000 \mathrm{Ci} \mathrm{mmol}^{-1}$ ) during 30 min treatment with $0.08 \%$ bile salts. The arrow shows the position of Gsp62.

and electroblotted onto a PVDF membrane. The general stress protein Gsp62 was then purified and N-terminal sequencing allowed the determination of the $25 \mathrm{~N}$ terminal amino acid sequence MDISVIDATKVNAETGLHIGESNAP. This sequence has been identified in the stress proteome of Ent. faecalis (Giard et al., 2001). Homology searches carried out with the BLAST program gave no significant similarities with sequences from databases. However, the corresponding ORF was obtained from the genomic sequence of Ent. faecalis (V583) available at http://www.tigr.org. The product of this ORF shares 24 aa with the $25 \mathrm{~N}$-terminal amino acid sequence of Gsp62 (the alanine in position 13 of Gsp62 was substituted by a threonine in the sequence deduced from the Ent. faecalis V583 genome). Translation of the entire ORF revealed that it encodes a 172 aa protein with a calculated molecular mass of $19.5 \mathrm{kDa}$ and a pI of 4.68. From this entire sequence, no significant similarities were found with proteins from databases. The hydrophobicity profile of Gsp62 showed a hydrophobic domain located between amino acids in positions 130 and 155 (data not shown). The nucleotide sequence immediately upstream of this ORF contains a putative ribosome-binding site (GAGG) located 6 bp upstream of the initiation codon (ATG). An inverted repeat $(\Delta G$
$=-33.8 \mathrm{kcal} \mathrm{mol}^{-1}$ ), which could act as a rho-independent terminator, was observed immediately downstream of the gsp62 termination codon TAA (Fig. 1a).

\section{Phenotypic study of the gsp62 mutant}

Because of the induction of Gsp62 synthesis under stress conditions, we examined whether a knockout of the gene affected stress resistance. A gsp62 mutant was constructed by homologous recombination as described in Methods. Growth studies of the gsp62 mutant did not reveal any significant difference with respect to the wildtype $\mathrm{JH} 2-2$ strain when cultured at $37^{\circ} \mathrm{C}$ in $\mathrm{BHI}$ broth. Gsp62 is thus dispensable for optimal growth. When assessing the survival of bacteria after different individual lethal treatments, we observed no significant differences between the two strains after heat, $\mathrm{NaCl}$, $\mathrm{pH}$, detergents, $\mathrm{tBOOH}$ and $\mathrm{H}_{2} \mathrm{O}_{2}$ challenges applied either with or without previous adaptation.

We examined whether the knockout confers modifications to the protein pattern observable on 2-D PAGE. 2-D PAGE of proteins extracted from exponentially growing JH2-2 and gsp62 mutant cells exposed to $0.08 \%$ bile salts (Fig. 3) or $2 \mathrm{mM} \mathrm{H}_{2} \mathrm{O}_{2}$ (data not shown) for 
(a)

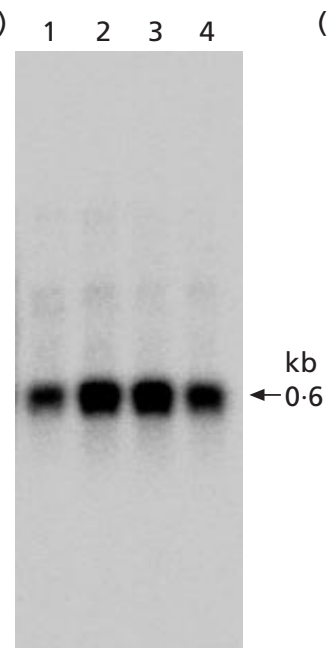

(c)
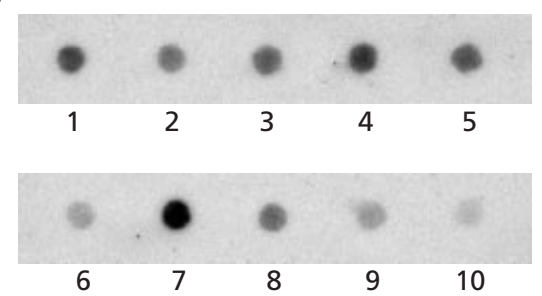

Fig. 4. (a) Northern blot hybridization of Ent. faecalis $\mathrm{JH} 2-2$ RNA extracted from exponentially growing cells (lane 1) and from cells incubated 10, 20 and 30 min with $0.08 \%$ bile salts (lanes 2, 3 and 4, respectively). Hybridization was performed with a single-strand DNA probe corresponding to the DNA region located between primers P4 and P5 (Fig. 1a; Table 2). The size of the transcript is indicated on the right. (b) Northern blot hybridization of Ent. faecalis JH2-2 RNA extracted from exponentially growing cells (lane 1 ) and from cells harvested at the entrance into stationary phase (lane 2). Hybridization was performed as in (a). (c) Dot blot hybridization of total RNA from Ent. faecalis $\mathrm{JH} 2-2$ cells harvested in exponential growth phase (dot 10), and from exponentially growing cells incubated $10 \mathrm{~min}$ at $50^{\circ} \mathrm{C}$, in the presence of $1.02 \mathrm{M} \mathrm{NaCl}, 4 \%$ ethanol, $0.08 \%$ bile salts, $0.01 \%$ SDS, $2.4 \mathrm{mM} \mathrm{H}_{2} \mathrm{O}_{2}$ or $2 \mathrm{mM} \mathrm{tBOOH}$ (dots $1-7$, respectively), or in GM17 medium adjusted to $\mathrm{pH} 4.8$ or 10.5 (dots 8 and 9). Hybridization was performed as in (a).

30 min confirmed the absence of Gsp62 in the mutant, but revealed no other significant difference in protein synthesis between the gsp62 mutant and the wild-type strains.

\section{Transcriptional analysis of $g s p 62$}

gsp62 is preceded by ORFs encoding proteins of unknown functions, while an ORF encoding a protein $80 \%$ identical to the ClpP protease of Listeria monocytogenes (Gaillot et al., 2000) is located downstream of gsp62 on the other DNA strand (Fig. 1a: ORFB). Northern blot analysis of Ent. faecalis RNA revealed a unique gsp62 transcript of $0.6 \mathrm{~kb}$ (Fig. $4 \mathrm{a}, \mathrm{b}$ ), demonstrating that the gsp62 mRNA is monocistronic. The Northern blot experiments also showed an unambigu-

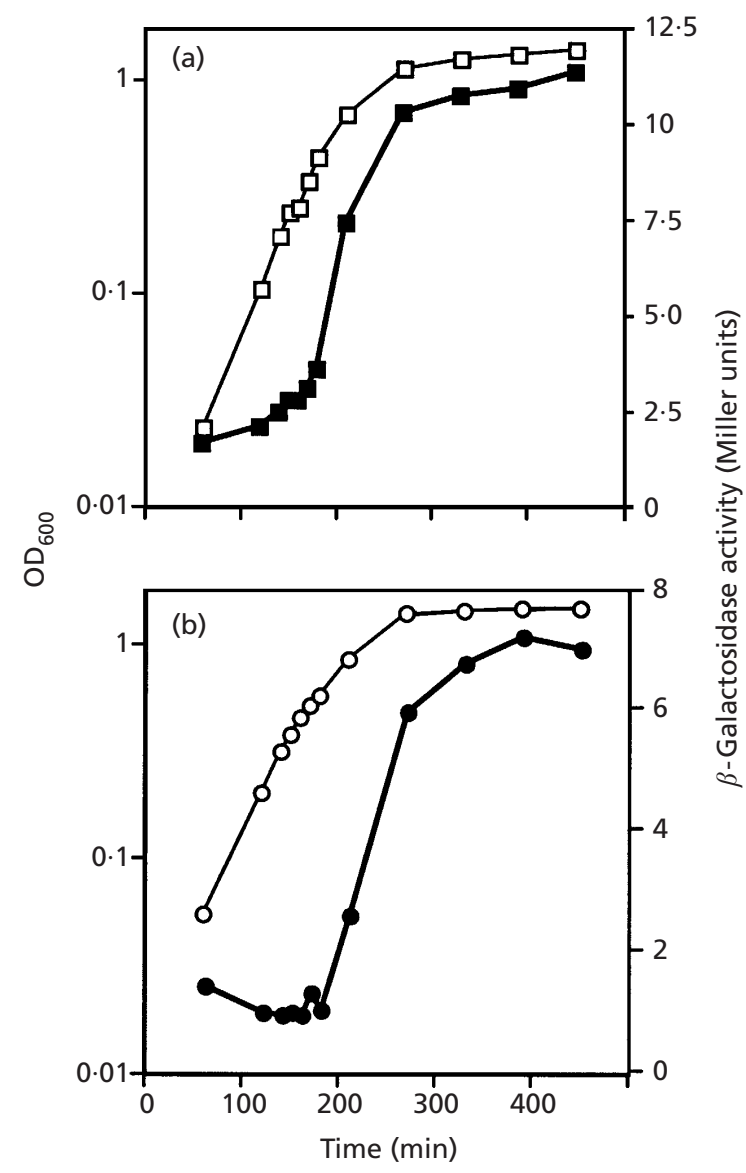

Fig. 5. gsp62 promoter activities during growth of Ent. faecalis $\mathrm{JH} 2$-2. The strain contains the $\beta$-galactosidase genes lacL and lacM under the control of the wild-type gsp62 promoter in pFWT62 (a) or the promoter deleted of the EcoRI fragment (Fig. 1a) in pFDE62 (b). $\mathrm{OD}_{600}$ (white symbols) and $\beta$-galactosidase activities (black symbols) were determined during the growth at $37^{\circ} \mathrm{C}$ in $\mathrm{BHI}$ medium.

ous induction of gsp62 transcription by the presence of bile salts, with a maximum mRNA accumulation observed $10 \mathrm{~min}$ after stress exposure (Fig. 4a) and by the entrance into stationary phase (Fig. 4b).

To analyse the effect of different stress conditions on gsp62 expression, dot blot experiments were carried out on total RNA extracted from exponentially growing cells or from bacteria incubated for $10 \mathrm{~min}$ with a sublethal dose of various agents (Fig. 4c). Results revealed that the transcription of $g s p 62$ is also stimulated by the presence of $2 \mathrm{mM} \mathrm{tBOOH}$, by an elevation of the temperature to $50{ }^{\circ} \mathrm{C}$, by incubation at $\mathrm{pH} 4.8$, in the presence of $0.01 \%$ SDS, $4 \%$ ethanol, and, to a lesser extent, with $1.02 \mathrm{M} \mathrm{NaCl}$ or $2.4 \mathrm{mM} \mathrm{H}_{2} \mathrm{O}_{2}$.

\section{Mapping of the transcriptional start site of gsp62}

To identify the promoter of gsp62, 5' RACE PCR experiments were carried out with RNA extracted from cells treated for $10 \mathrm{~min}$ with $2 \mathrm{mM} \mathrm{tBOOH}$. A unique 

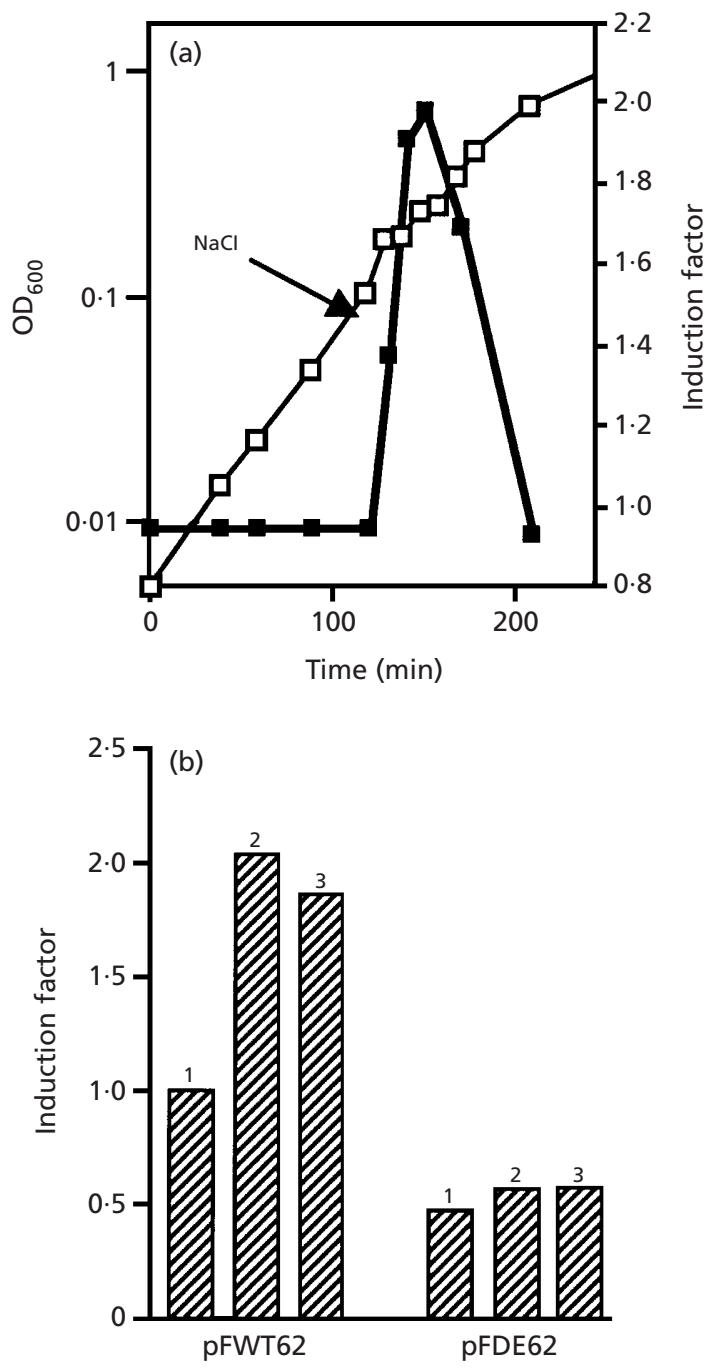

Fig. 6. (a) gsp62 promoter activities in Ent. faecalis $\mathrm{JH} 2-2$ cells containing plasmid pFWT62. $\mathrm{OD}_{600}$ (white squares) was determined during the growth at $37^{\circ} \mathrm{C}$ in $\mathrm{BHI}$ medium. After 120 min incubation, the culture was divided in two and either treated with $0.3 \mathrm{M} \mathrm{NaCl}$ (arrow) or untreated. $\beta$-Galactosidase activities were measured and expressed as the ratio of activity of the treated culture to activity of the untreated culture (induction factor: black symbols). (b) $\beta$-Galactosidase activities of Ent. faecalis JH2-2 cells containing plasmid pFWT62 or pFDE62. Measurements were carried out from exponentially growing cells untreated (1), or treated $10 \mathrm{~min}$ with $0.3 \mathrm{M} \mathrm{NaCl}$ (2) or $4 \%$ ethanol (3). Induction factors are the ratio of $\beta$-galactosidase activities of the tested condition to that obtained with the pFWT62 control in unstressed cells. Standard deviations for all conditions are not higher than 0.03.

band was observed after electrophoresis of the $5^{\prime}$ RACE PCR product and the sequence of the corresponding cDNA showed that the transcriptional start site of gsp 62 lies $21 \mathrm{nt}$ upstream of the ribosome-binding site (Fig. 1b). Seven base pairs upstream of this transcriptional start site, we found the putative -10 box TATACT separated by $17 \mathrm{bp}$ from the putative -35 box ATGATT. This promoter matches the consensus sequence for promoters depending on the primary sigma factor
(TATAAT-16-19 bp-TTGACA, respectively). Immediately upstream of the -35 box of the gsp62 promoter, an inverted repeat (IR) (AGgCACGAATTCA-7 bpTGAATTCGTGtCT) was identified (Fig. 1a).

\section{Construction of promoter fusions and $\beta$-galactosidase expression analyses}

Two promoter fusions with the lacL and lacM $\beta$ galactosidase genes were constructed as described in Methods. The first fusion corresponded to the wild-type gsp62 promoter (region -246 to +107 ) cloned upstream of the $\beta$-galactosidase genes of the pAK80 vector (plasmid pFWT62), while the second differed by a $15 \mathrm{bp}$ deletion which removed a part of the IR located immediately upstream of the -35 box (Fig. 1a) (plasmid pFDE62).

$\beta$-Galactosidase activity was monitored during the growth of Ent. faecalis JH2-2 harbouring pFWT62 or pFDE62. A strong increase $(6 \cdot 8$-fold) of the $\beta$-galactosidase activity was observed at the end of the exponential growth phase with the wild-type promoter (Fig. 5a). This confirms the gsp62 transcriptional induction at the entry into stationary phase. The transcriptional induction at the entry into stationary phase $(7 \cdot 2$-fold) was also observable with the deleted version of the promoter fragment (Fig. 5b), showing that this phenomenon does not rely on the IR located immediately upstream of the -35 box.

When a sublethal dose of salt ( $0 \cdot 3 \mathrm{M}$ sodium chloride) was added to the culture during the exponential growth phase of Ent. faecalis JH2-2 harbouring pFWT62, the $\beta$ galactosidase activity abruptly increased to reach an induction factor of 2.0 (which corresponded to 5.68 Miller units) $30 \mathrm{~min}$ after the addition of $\mathrm{NaCl}$ (Fig. 6a). The addition of ethanol $(4 \%)$ had a similar effect on the $\beta$-galactosidase activity with the wild-type promoter fusion (induction factor of $1 \cdot 8$ ) (Fig. 6b). With the disruption of the IR, the $\beta$-galactosidase activity was half that of the wild-type (Fig. 6b); challenge with sodium chloride or ethanol resulted in hardly any induction of $g s p 62$. This showed the involvement of the IR in the $g s p 62$ basal transcription and in its regulation by environmental stresses. Two distinct mechanisms are thus involved in induction of transcription in response to environmental and metabolic stresses.

\section{DISCUSSION}

To understand the mechanisms involved in Ent. faecalis stress resistance and particularly the multistress-resistance phenomenon, we chose to characterize general stress proteins. Our original biochemical studies of Ent. faecalis protein synthesis allowed the detection of seven general stress proteins (Gsp62-67 and Gls24), the synthesis of which was shown to be increased by different individual stresses (Giard et al., 2000; Rincé et al., 2000). In the present study, our aim was to characterize Gsp62. Gsp62 was purified after 2-D PAGE and its N-terminal sequence was determined. The 
knowledge of the $25 \mathrm{~N}$-terminal amino acids allowed us to identify the corresponding gene within the Ent. faecalis V538 genome and to conclude that Gsp62 does not share significant similarities with proteins from databases and can be considered as a novel general stress protein. gsp $62 \mathrm{mRNA}$ studies revealed that this gene is transcribed as a $0.6 \mathrm{~kb}$ monocistronic mRNA and gave evidence for a transcriptional induction when cells were exposed to elevated temperature, a $\mathrm{pH}$ decrease or to the presence of $\mathrm{tBOOH}$, ethanol, bile salts, SDS, $\mathrm{NaCl}$ and $\mathrm{H}_{2} \mathrm{O}_{2}$. These observations provide an unambiguous demonstration that Gsp62 is a general stress protein. gsp62 promoter activity is also clearly stimulated when bacteria enter the stationary phase, probably as a consequence of nutrient starvation. The expression of gsp62 is thus induced by both environmental and metabolic stresses. In this respect, gsp62 resembles Bacillus subtilis gsp genes belonging to class II, the induction of which is under the sole control of the general stress secondary sigma factor $\sigma^{\mathrm{B}}$ (Hecker et al., 1996; Hecker \& Völker, 1998).

We recently identified and characterized gsp65, another general stress protein encoding gene in Ent. faecalis (Rincé et al., 2001). The transcription of gsp62 and of gsp65 is induced to comparable levels by the same treatments, suggesting that those two genes belong to the same regulon.

5 ' RACE PCR product sequencing allowed us to locate the gsp62 promoter, which matches the consensus sequence for the primary sigma factor. Immediately upstream of this promoter, an IR was identified. Upstream of the previously described gsp 65 promoter, an IR of distinct sequence was also identified (Rincé et al., 2001). As gsp65 is preceded by a gene located on the other DNA strand, we suggested that the gsp65 IR was unlikely to be a rho-independent terminator, but rather a structure potentially involved in transcriptional regulation (Rincé et al., 2001). Here, results from gsp62 promoter fusions with $\beta$-galactosidase genes revealed that the disruption of the IR led to a reduction of the basal level of transcription and prevented environmental stress induction of gsp62. This IR is thus very likely a target of a regulator (activator) of general stress response in Ent. faecalis. The induction of gsp62 expression in response to environmental stresses is thus not due to a secondary sigma factor. Whereas a gene encoding a $\sigma^{\mathrm{B}}$ homologue has been identified in some non-sporulating Gram-positive bacteria (Becker et al., 1998; Wiedmann et al., 1998; Wu et al., 1996), no alternative sigma factor has been identified in the Ent. faecalis V583 chromosome sequence. Moreover, in Lactococcus lactis, which is closely related to Ent. faecalis and the genome of which has been entirely sequenced (Bolotin et al., 1999), no $\sigma^{\mathrm{s}}$ or $\sigma^{\mathrm{B}}$-like transcription factor has been found. Surprisingly, the deletion of a part of the IR had no effect on the activation of gsp62 promoter in response to entry into stationary phase. This implies that in contrast to $B$. subtilis class II gsp genes, gsp62 relies on two completely distinct pathways of induction responding to different signals.

\section{ACKNOWLEDGEMENTS}

The expert technical assistance of Annick Blandin and Béatrice Gillot was greatly appreciated. M. Uguen was the recipient of a doctoral fellowship from the 'Region Bretagne'.

\section{REFERENCES}

Altschul, S. F., Gish, W., Miller, W., Myers, E. W. \& Lipman, D. J. (1990). Basic local alignment search tool. J Mol Biol 215, 403-410.

Bardonnet, N. \& Blanco, C. (1992). ' uidA-antibiotic-resistance cassettes for insertion mutagenesis, gene fusions and genetic constructions. FEMS Microbiol Lett 93, 243-247.

Becker, L. A., Cetin, M. S., Hutkins, R. W. \& Benson, A. K. (1998). Identification of a gene encoding the alternative sigma factor $\sigma^{\mathrm{B}}$ from Listeria monocytogenes and its role in osmotolerance. $J$ Bacteriol 180, 4547-4554.

Bolotin, A., Manger, S., Malarme, K., Ehrlich, S. D. \& Sorokin, A. (1999). Low-redundancy sequencing of the entire Lactococcus lactis IL1403 genome. Antonie Leeuwenhoek 76, 27-76.

Boutibonnes, P., Giard, J. C., Hartke, A., Thammavongs, B. \& Auffray, Y. (1993). Characterization of the heat shock response in Enterococcus faecalis. Antonie Leeuwenhoek 64, 47-55.

Dower, J. W., Miller, J. F. \& Ragsdale, C. W. (1988). High efficiency transformation of E. coli by high voltage electroporation. Nucleic Acids Res 16, 6127-6145.

Flahaut, S., Benachour, A., Giard, J. C., Boutibonnes, P. \& Auffray, Y. (1996a). Defense against lethal treatments and de novo protein synthesis induced by $\mathrm{NaCl}$ in Enterococcus faecalis ATCC 19433. Arch Microbiol 165, 317-324.

Flahaut, S., Frère, J., Boutibonnes, P. \& Auffray, Y. (1996b). Comparison of the bile salts and sodium dodecyl sulfate stress responses in Enterococcus faecalis. Appl Environ Microbiol 62, 2416-2420.

Flahaut, S., Hartke, A., Giard, J. C., Benachour, A., Boutibonnes, P. \& Auffray, Y. (1996c). Relationship between stress response toward bile salts, acid and heat treatment in Enterococcus faecalis. FEMS Microbiol Lett 138, 49-54.

Flahaut, S., Boutibonnes, P. \& Auffray, Y. (1997a). Les Enterocoques dans l'environnement proche de l'homme. Can J Microbiol 43, 699-708.

Flahaut, S., Frère, J., Boutibonnes, P. \& Auffray, Y. (1997b). Relationship between the thermotolerance and the increase of DnaK and GroEL synthesis in Enterococcus faecalis ATCC19433. J Basic Microbiol 37, 251-258.

Flahaut, S., Hartke, A., Giard, J. C. \& Auffray, Y. (1997c). Alkaline stress response in Enterococcus faecalis: adaptation, crossprotection, and changes in protein synthesis. Appl Environ Microbiol 63, 812-814.

Flahaut, S., Laplace, J. M., Frère, J. \& Auffray, Y. (1998). The oxidative stress response in Enterococcus faecalis: relationship between $\mathrm{H}_{2} \mathrm{O}_{2}$ tolerance and $\mathrm{H}_{2} \mathrm{O}_{2}$ stress proteins. Lett Appl Microbiol 26, 259-264.

Frère, J., Benachour, A., Novel, M. \& Novel, G. (1993). Identification of the theta-type minimal replicon of the Lactococcus lactis subsp. lactis CNRZ270 lactose protease plasmid pUCL22. Curr Microbiol 27, 97-102.

Gaillot, O., Pellegrini, E., Bregenholt, S., Nair, S. \& Berche, P. (2000). The ClpP serine protease is essential for the intracellular parasitism and virulence of Listeria monocytogenes. Mol Microbiol 35, 1286-1294. 
Giard, J. C., Hartke, A., Flahaut, S., Benachour, A., Boutibonnes, P. \& Auffray, Y. (1997). Glucose starvation response in Enterococcus faecalis JH2-2: survival and proteins analysis. Res Microbiol 148, 27-35.

Giard, J. C., Rincé, A., Capiaux, H., Auffray, Y. \& Hartke, A. (2000). Inactivation of the stress- and starvation-inducible $g l s 24$ operon has a pleiotropic effect on cell morphology, stress sensitivity and gene expression in Enterococcus faecalis. J Bacteriol 182, 45124520.

Giard, J. C., Laplace, J. M., Rincé, A., Pichereau, V., Benachour, A., Leboeuf, C., Flahaut, S., Auffray, Y. \& Hartke, A. (2001). The stress proteome of Enterococcus faecalis. Electrophoresis 22, 29472954.

Hecker, M. \& Völker, U. (1998). Non-specific general and multiple stress resistance of growth-restricted Bacillus subtilis cells by the expression of the $\sigma^{\mathrm{B}}$ regulon. Mol Microbiol 29, 1129-1136.

Hecker, M., Schumann, W. \& Völker, U. (1996). Heat-shock and general stress response in Bacillus subtilis. Mol Microbiol 19, 417-428.

Holo, H. \& Nes, I. F. (1995). Transformation of Lactococcus by electroporation. Methods Mol Biol 47, 195-199.

Israelsen, H., Madsen, S. M., Vrang, A., Hansen, E. B. \& Johansen, E. (1995). Cloning and partial characterization of regulated promoters from Lactococcus lactis Tn917-lacZ integrants with the new promoter probe vector, pAK80. Appl Environ Microbiol 61, 2540-2547.

Jett, B. D., Huycke, M. M. \& Gilmore, M. S. (1994). Virulence of enterococci. Clin Microbiol Rev 7, 462-478.

Jones, D. \& Shattock, P. M. (1960). The location of the group antigen of group D Streptococcus. J Gen Microbiol 23, 335-343.

Laplace, J. M., Boutibonnes, P. \& Auffray, Y. (1996). Unusual resistance and acquired tolerance to cadmium chloride in Enterococcus faecalis. J Basic Microbiol 36, 311-317.
Miller, J. M. (1972). Experiments in Molecular Genetics. Cold Spring Harbor, NY: Cold Spring Harbor Laboratory.

Mundt, J. O. (1986). Enterococci. In Bergey's Manual of Systematic Bacteriology, pp. 1063-1065. Edited by P. H. A. Sneath, N. S. Mair, M. E. Sharpe \& J. G. Holt. Baltimore: Williams \& Wilkins.

Rincé, A., Flahaut, S. \& Auffray, Y. (2000). Identification of general stress genes in Enterococcus faecalis. Int J Food Microbiol 55, 87-91.

Rincé, A., Giard, J. C., Pichereau, V., Flahaut, S. \& Auffray, Y. (2001). Identification and characterization of gsp65, an organic hydroperoxide resistance $(o h r)$ gene encoding a general stress protein in Enterococcus faecalis. J Bacteriol 183, 1482-1488.

Sambrook, J., Fritsch, E. F. \& Maniatis, T. (1989). Molecular Cloning: a Laboratory Manual, 2nd edn. Cold Spring Harbor, NY: Cold Spring Harbor Laboratory.

Terzaghi, B. E. \& Sandine, W. E. (1975). Improved medium for lactic streptococci and their bacteriophages. Appl Environ Microbiol 29, 807-813.

Wiedmann, M., Arvik, T. J. \& Boor, K. J. (1998). General stress transcription factor $\sigma^{\mathrm{B}}$ and its role in acid tolerance and virulence of Listeria monocytogenes. J Bacteriol 180, 3650-3656.

Wu, S., de Lencastre, H. \& Tomasz, A. (1996). Sigma-B, a putative operon encoding alternate sigma factor of Staphylococcus aureus RNA polymerase: molecular cloning and DNA sequencing. $J$ Bacteriol 178, 6036-6042.

Yagi, Y. \& Clewell, D. B. (1980). Recombination-deficient mutant of Streptococcus faecalis. J Bacteriol 143, 966-970.

Received 18 July 2001; revised 8 October 2001; accepted 11 October 2001. 